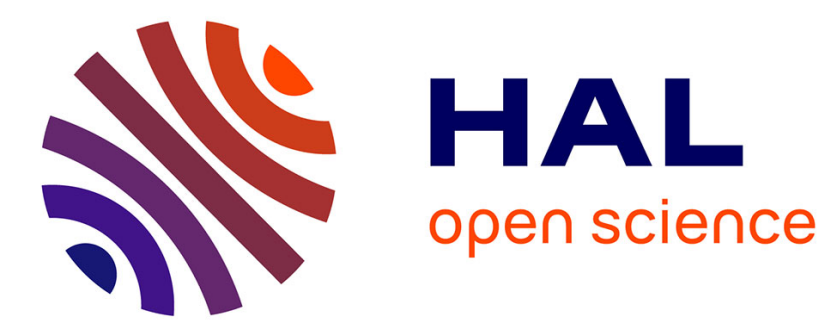

\title{
Acute amnestic encephalopathy in amyloid-beta oligomer-injected mice is due to their widespread diffusion in vivo
}

Stephane Epelbaum, Ihsen Youssef, Pascale N. Lacor, Pierre Chaurand, Eric Duplus, Bernard Brugg, Charles Duyckaerts, Benoit Delatour

\section{To cite this version:}

Stephane Epelbaum, Ihsen Youssef, Pascale N. Lacor, Pierre Chaurand, Eric Duplus, et al.. Acute amnestic encephalopathy in amyloid-beta oligomer-injected mice is due to their widespread diffusion in vivo. Neurobiology of Aging, 2015, 36 (6), pp.2043-2052. 10.1016/j.neurobiolaging.2015.03.005 . hal-01544165

\section{HAL Id: hal-01544165 \\ https://hal.science/hal-01544165}

Submitted on 25 May 2021

HAL is a multi-disciplinary open access archive for the deposit and dissemination of scientific research documents, whether they are published or not. The documents may come from teaching and research institutions in France or abroad, or from public or private research centers.
L'archive ouverte pluridisciplinaire HAL, est destinée au dépôt et à la diffusion de documents scientifiques de niveau recherche, publiés ou non, émanant des établissements d'enseignement et de recherche français ou étrangers, des laboratoires publics ou privés. 


\title{
Acute amnestic encephalopathy in amyloid-ß oligomers injected mice is due to their widespread diffusion in vivo
}

\author{
Stéphane Epelbaum, $\mathrm{MD}^{\mathrm{a}, \mathrm{b}}$, Ihsen Youssef, $\mathrm{PhD}^{\mathrm{a}}$, Pascale N. Lacor $\mathrm{PhD}^{\mathrm{c}}$, Pierre Chaurand, $\mathrm{PhD}^{\mathrm{d}}$, Eric Duplus, \\ $\mathrm{PhD}^{\mathrm{e}}$,Bernard Brugg, $\mathrm{PhD}^{\mathrm{e}}$, Charles Duyckaerts, MD PhD ${ }^{\mathrm{a}, \mathrm{f}}$, Benoît Delatour PhD ${ }^{\mathrm{a} *}$
}

\footnotetext{
a Sorbonne Universités, UPMC Univ Paris 06 UMR S 1127, and Inserm, U 1127, and CNRS UMR 7225, and ICM,

47 Bd de l'Hôpital, 75013, Paris, France

${ }^{\mathrm{b}}$ Institut de la mémoire et de la maladie d'Alzheimer, Département de neurologie, Hôpital de la Pitié Salpêtrière, 47

Bd de l'Hôpital, 75013, Paris, France

${ }^{\mathrm{c}}$ Department of Neurobiology, Northwestern University, Evanston, IL 60208, USA

${ }^{\mathrm{d}}$ Department of Chemistry, Université de Montréal, Montreal, Canada

${ }^{\mathrm{e}}$ CNRS-UPMC UMR 8256, Biological Adaptation and Ageing ( B2A), Université P. et M.Curie,

Team: Degenerative Processes in Neurons and Networks (DP2N), 9 quai St Bernard, 75252, Paris, France

${ }^{\mathrm{f}}$ Laboratoire de neuropathologie Escourolle, Hôpital de la Pitié Salpêtrière, 47 Bd de l'Hôpital, 75013, Paris, France
}

* Corresponding author: stephane.epelbaum@psl.aphp.fr Tel +331 42167522 


\section{Abstract}

Amyloid- $\beta(A ß)$ oligomers are the suspected culprit as initiators of Alzheimer's disease (AD). However their diffusion in the brain remains unknown.

Here, we studied $A ß$ oligomers dissemination and evaluated their in vivo toxicity. Wild-type mice were injected with 50 picomoles of synthetic $\mathrm{A} ß$ oligomers (of different size) in the hippocampus.

Oligomers diffused largely in the brain as soon as 1 hour and up to 7 days after injection. A transient encephalopathy with memory impairment was induced by this unique injection. The immunoreactivity of the post synaptic marker PSD95 was diffusely decreased. Similar results (both on memory and PSD95 immunoreactivity) were obtained with delipidated and high molecular weight oligomers $(>50 \mathrm{kDa})$ but not with smaller assemblies. Tau hyperphosphorylation was observed in oligomer-injected brains. Finally, fos immunostaining was increased in ADDLs injected mice, suggesting neuronal hyperactivity.

Rapid and widespread diffusion of $\mathrm{A} ß$ oligomers was demonstrated in vivo and associated with decreased synaptic markers and memory deficits which gives new insight to the pathogenicity of $A ß$.

\section{Key words}

Alzheimer's disease; Amyloid B; Oligomers; in vivo animal model; neurotoxicity. 


\section{Introduction}

Diagnosis of Alzheimer's disease (AD) relies on two hallmark lesions: extracellular deposits of betaamyloid peptides (Aß deposits) and intraneuronal aggregates of hyperphosphorylated Tau protein (neurofibrillary tangles) (Duyckaerts, et al., 2009). A current physiopathological hypothesis states that the overproduction or insufficient clearance of $A \beta$ is the event that induces a cascade of secondary brain alterations (synaptic damage, inflammation, tau hyperphosphorylation, neuronal death) leading to dementia (Hardy and Selkoe, 2002,Hardy and Higgins, 1992). This sequence of events has, however, never been reproduced by injecting fibrillar or monomeric A $\beta$ peptides in the brain of animals (Games, et al., 1992) ; moreover, the failure of recent therapeutic trials in which a reduction of the amyloid load did not modify the progression of the symptoms does not support the amyloid cascade hypothesis (Doody, et al., 2014,Gilman, et al., 2005,Holmes, et al., 2008,Salloway, et al., 2014). One hypothesis to explain these failures could be that the toxic $A ß$ species have not been specifically targeted (Goure, et al., 2014). Experimental data from the last decade suggest indeed a revision of the model. Numerous reports show that the toxic pool of $A \beta$ is not made of extracellular aggregates, but of soluble oligomeric molecular assemblies (Selkoe, 2008). The failure of the cascade hypothesis model could hence be related to its emphasis on the concentration of $\mathrm{A} \beta$ rather than on the aggregation state of the peptide: hence fibrils of $A ß$ are more toxic than monomers but less than oligomers in vitro (Chromy, et al., 2003). Oligomers are aggregates of $A \beta$ that remain soluble and show an exquisite synapto-toxicity. Solubility-diffusibility and/or active transport are required to explain the spreading of A $\beta$ toxicity but have not yet been thoroughly analyzed in vivo.

Synthetic $A ß$ oligomers such as $A \beta$ Derived Diffusible Ligands (ADDLs) have been shown to be10 times more neurotoxic in vitro than fibrillar A $\beta$, and 50 times more toxic than monomeric A $\beta$ (Lambert, et al., 1998,Stine Jr, et al., 2003). ADDLs colocalize with PSD95, a marker of postsynaptic densities (Lacor, et al., 2004). They alter the shape, composition and density of synapses (Lacor, et al., 2007). They modify mGluR5 receptor clustering and lateral diffusion at the cell membrane triggering an intracellular calcium influx and causing drastic synaptic changes (Renner, et al., 2010). Only few studies have investigated the effects of in vivo administration of Aß oligomers. Injections of different types of $A ß$ oligomers in the lateral ventricles acutely induce marked memory impairments 
(Balducci, et al., 2010,Cleary, et al., 2005,Garcia, et al., 2010,Youssef, et al., 2008). Unilateral injection restricted to the hippocampus is sufficient to induce a general deficit in memory (Moon, et al., 2011,Pearson-Leary and McNay, 2012) while a localized lesion of the hippocampus should not cause such impairments (Moser, et al., 1995). A diffusion of the $A \beta$ oligomers or a widespread reaction to its local injection could explain the severity of the symptoms. It has been hypothesized that induced memory impairments are tightly associated with the synaptotoxic effects of oligomers (Selkoe, 2008). Widespread synaptic dysfunction is nonetheless required to promote behavioral effects. This implies large diffusion of Aß oligomers through the brain parenchyma but in vivo evidence is currently lacking.

In the present study, $\mathrm{A}$ oligomers diffusion and toxicity were studied after injection of various types of ADDLs in wild-type mice. The consequences of a unique injection in the hippocampal formation (hippocampus or adjacent rhinal cortex) were examined. As lipids have been suggested to act as co-factors for Aß-induced toxicity (Hong, et al., 2014,Martins, et al., 2008), both regular ADDLs (synthetized in lipid containing medium) and delipidated ADDLs were tested for their toxicity. The diffusion of A $\beta$ species in brain parenchyma was assessed by different methods (histological mapping and imaging mass spectrometry -IMS (Chaurand, 2012,Cornett, et al., 2007)). Local and distant synaptotoxic effects were quantified as well as other neuropathological alteration (tau phosphorylation, changes in evoked neuronal activity). Consequences of ADDLs injection on learning and memory tasks were also analyzed.

\section{Materials and Methods}

\subsection{Oligomers preparation \& characterization}

Untagged human A $\beta 1-42$ peptide (California Peptide Research, Napa, CA, USA) or N-terminal tagged A $\beta 1$ 42 peptides with either HiLyte FluorTM 555 (Anaspec, Fremont, CA, USA) or biotin (California Peptide Research) were used to prepare ADDLs according to published protocols (Klein, 2002,Lacor, et al., 2004,Lambert, et al., 1998,Renner, et al., 2010). Molecular weight (MW) fractionation of oligomeric species was obtained with Centricon YM-50 concentrators (Millipore, Bedford, MA, USA), used according to manufacturer's instructions as previously described (Lacor, et al., 2004). Filtrate low MW ADDLs (below 50 kDa) and retentate high MW ADDLs (above 50 $\mathrm{kDa}$ ) were obtained. Alternatively ADDLs were prepared in a delipidated environment by substituting the regular 
F12 medium with a customized medium deprived of lipids (linoleic and lipoic acids) (Caisson Laboratories, North Logan, UT, USA). A vehicle solution (dilution solvent or dilution solvent with added free biotin) or a solution of scrambled A $\beta 1-42$ peptides (California Peptide Research) was used as control injectates.

Prior to in vivo injection, each ADDL solution was tested for proper synaptic binding and toxicity in matured hippocampal neurons cultures as previously described (Lacor, et al., 2004,Lacor, et al., 2007).

For in vivo experiments, the amount of injected oligomers was calculated to reach a cerebral concentration of the same order of magnitude as the concentration of soluble A $\beta$ observed in AD brains, i.e. less than $1 \mu \mathrm{g} / \mathrm{g}$ (McLean, et al., 1999). One $\mu 1$ of a $50 \mu \mathrm{M}$ solution was injected i.e. 50 picomoles of $A ß$ monomer equivalent. We therefore injected $0,225 \mu \mathrm{g}$ of $\mathrm{A} B$ in adult mouse brains weighting around $500 \mathrm{mg}$. If the ADDLs were freely diffusing in that volume, their final concentration would be $0,45 \mu \mathrm{g} / \mathrm{g}$.

\subsection{Animals}

Twelve weeks old C57B1/6 male mice (Janvier, Saint Berthevin, France) were used. One hundred and forty one mice were injected in total either with ADDLs or with control solutions. Mice were habituated for one week to their new environment before initiating surgery. The general health of the mice was regularly checked and body weights were assessed weekly throughout the experimental period. All experiments on animals were conducted in accordance with the ethical standards of French and European laws (European Communities Council Directive 2010/63/EU on the protection of animals used for scientific purposes). The supervisor of the present study (B. D.) has received official agreements from the French Ministry of Agriculture to carry out research and experiments on animals (authorization No. A-75-1741). The project was approved by the local Ethics committee (Charles Darwin committee; project $\left.\mathrm{N}^{\circ} 643.01\right)$.

\subsection{Stereotactic injections}

The general design of the experiments and the allocation of mice are described in Fig. 1. Mice were anesthetized (ketamine $100 \mathrm{mg} / \mathrm{kg}$, xylazine $10 \mathrm{mg} / \mathrm{kg}$ intra-peritoneally). One $\mu \mathrm{l}$ of ADDLs solution or $1 \mu \mathrm{l}$ of a control solution was injected in the right hippocampus using a Hamilton syringe (1701 RN $10 \mu \mathrm{L}$, Hamilton, Bonaduz, GR, Switzerland) equipped with a 33G steel needle (Dominique Dutscher, Brumath, France) and mounted on a nano-pump syringe (KDS310 Syringe Pump, KD Scientific, Holliston, MA, USA). 
The coordinates of the injections sites were adapted from the Franklin and Paxinos atlas (Paxinos and Franklin, 2004): AP: -2,2 mm from Bregma; ML: +1,3 mm from midline ; DV: $-1,9 \mathrm{~mm}$ from dura. Oligomers were injected over a $5 \mathrm{~min}$ period $(0,2 \mu \mathrm{l} / \mathrm{min})$ and the needle was left in place for another $5 \mathrm{~min}$ after injection.

\subsection{Behavioral analysis}

Spatial memory: Six or thirty days after injection spatial memory was assessed in a Y-maze paradigm. Environmental conditions were kept constant (13 lux luminosity and $60 \mathrm{~dB}$ white noise). The mouse was placed in a transparent plexiglas Y-maze (height: $20 \mathrm{~cm}$; width $12 \mathrm{~cm}$ and length: $26 \mathrm{~cm}$ ) with one arm closed by an opaque door and allowed to freely explore the other two arms for $10 \mathrm{~min}$. Mice were then replaced in their home cage for a 15 min delay. After the delay period mice were re-introduced in the maze (previously cleaned with ethanol $70^{\circ}$ in order to remove olfactory cues) with all three arms available. They were given a $5 \mathrm{~min}$ free exploration trial. During the test, the mouse was filmed with a camera and its activity automatically recorded and analyzed by a videotracking system (AnyMaze, Stoelting, Wood Dale, IL, USA). The travelled distance, the number of arms visited and the discrimination index (I) were recorded. The index I is a measure of memory performance (I= time spent in the new arm / time spent in all 3 arms expressed in \%; chance level: 33\%).

Exploration of a novel environment: A subgroup of 16 animals was behaviorally stimulated to study evoked neuronal activity mapped by fos protein, an immediate gene product used as a marker of neuronal activation (Terleph and Tremere, 2006), immunoreactivity (see Fig. 1). Seven days after surgery, the mice were placed in an openfield (in the aforementioned environmental conditions) in which 4 objects had been placed to provide visual-tactile cues and stimulate exploration. After ten minutes in the openfield the animals were placed in their homecage where they remained for 90 minutes before being sacrificed. The 90 minutes delay was selected to maximize post-stimulation fos expression.

\subsection{Tissue preparation}

Mice were sacrificed 1 hour to 30 days after injection. For all experiments except MS imaging (see below) mice were anaesthetized with pentobarbital $(120 \mathrm{mg} / \mathrm{kg})$ and then transcardially perfused with $4 \%$ paraformaldehyde. The brain was extracted, cryoprotected in a $2 \%$ - DMSO - $20 \%$ glycerol solution and finally cut on a freezing microtome (serial sections of $40 \mu \mathrm{m}$ of the entire brain). 


\subsection{Histology}

Injected ADDLs: Tissue samples from mice injected with ADDLs tagged by Fluor Hylite 555 were directly mounted on glass slides (Superfrost ${ }^{\circledR}$ plus, Menzel-glaser GmbH, Braunsheig, Germany). Tissue samples from mice injected with biotinylated ADDLs were revealed by the avidin-biotin technique following the manufacturer's recommendations (ABC Elite kit, Vector labs, Burlingame, CA, USA).

Immunohistochemistry: the sections were first pretreated with hydrogen peroxide to block endogenous peroxidases activity. Different primary antibodies were used (Table 1). Noticeably ADDLs detection was assessed by two concurrent antibodies: OC that recognizes fibrillar oligomers (Kayed, et al., 2007) and NU1 that was obtained after mouse immunization with ADDLs and is well characterized for its specificity to oligomer Aß without crossreacting monomeric or high-molecular weight fibrillar Aß (Lambert, et al., 2007). NU1 is able to recognize early Aß deposits corresponding to pre-plaques oligomeric material (see Sup Fig 1 c-d). Following blockade of non-specific antigenic sites with goat serum 5\%, were then incubated overnight at room temperature (except for fos antibody that was incubated 48 hours at $4^{\circ} \mathrm{C}$ ). The sections were then incubated with the secondary biotinylated antibodies for two hours (Table 1). The secondary antibody was detected by the peroxidase-avidin-biotin technique with 3,3'diaminobenzidine (DAB -Sigma-Aldrich, Saint-Quentin Fallavier, France) or DAB enriched with nickel salt (DABNi) as chromogen. Sections were then collected on Superfrost glass slides, air-dried and finally dehydrated and cleared in grading alcohols and xylene and mounted in Eukitt mounting medium (EMS, Hatfield, PA, USA). Immunofluorescence: the sections were treated for 2 hours as previously described but the secondary antibodies were coupled to specific fluorochromes (see Table 1). The sections were collected on Superfrost glass slides and mounted in VECTASHIELD® Hard Set ${ }^{\mathrm{TM}}$ Mounting Medium with DAPI (Vector Laboratories), an aqueous medium containing DAPI to stain nuclei.

\subsection{Images acquisition \& analysis}

The histological slides were examined with an Apotome.2 system for fluorescence microscopy or a Zeiss Scope .A1 for brightfield microscopy (Zeiss, Oberkochen, Germany). Digital pictures were acquired with the Axiovision (Zeiss) software. Microscopic scans of whole sections (pixel size $0.25 \mu \mathrm{m}^{2}$ ) were acquired with a Nanozoomer 2.0 RS slide scanner (Hamamatsu Photonics, Hamamatsu, Japan). 
To evaluate the presence of biotinylated ADDLs in brain tissues, 3 observers (SE, BD \& CD) assessed the slides blinded to the nature of the injectate. The staining was considered positive when a diffuse DAB signal could be evidenced by all three assessors and negative otherwise.

Following PSD95 immunohistochemistry, hippocampus, prefrontal cortex and corpus callosum were manually outlined on digitized sections. The mean grey value $(\mathrm{GV})$ of the pixels in each region was then assessed using image analysis software ImageJ (Fiji Package) (Schindelin, et al., 2012) and converted to optical density (OD) using the formula $\mathrm{OD}=\log (256 /(\mathrm{GV}+1))$. OD were normalized relative to the staining of the corpus callosum, which served as baseline value to obtain relative optical densities (ROD). Similar analyses were performed to evaluate AT8 immunostaining: OD were measured in 3 regions of interest (dorsal hippocampus and prefrontal cortex).

Cell counts after fos immunostaining were performed using ICY, an open source software (http://icy.bioimageanalysis.org) (Braudeau, et al., 2011,de Chaumont, et al., 2012). The hippocampus and the prefrontal cortex were delineated in both hemispheres. The numbers and areas of fos-positive neurons (ICY spot detector plugin) were automatically detected with the same settings applied to all slices / animals (Scale 2, Threshold 100) (Olivo-Marin, 2002). The ratio "area labeled by the anti-fos antibody / area of the region of interest" was used as a quantitative unbiased measure of fos immunostaining.

\subsection{Imaging mass spectrometry}

Matrix-assisted laser desorption ionization and imaging mass spectrometry (MALDI IMS) was used to test the diffusion of the ADDLs. Mice were euthanized by cervical dislocation one hour after injection. Their brain was immediately snap-frozen by immersion in liquid nitrogen. Ten $\mu$ m-thick coronal brain sections were obtained at the level of the injection point using a cryostat (CM3050 cryostat, Leica Microsystem GmbH, Wetzlar, Germany) and mounted on conductive indium-tin oxide coated glass slides (Delta Technologies Ltd, Loveland, CO, USA). The MALDI matrix (sinapinic acid at $4 \mathrm{mg} / \mathrm{ml}$ in $60: 40$ acetonitrile: $0,2 \%$ trifluoroacetic acid) was automatically deposited on the tissue sections using a chemical printer (CHiP 1000, Shimadzu Corporation, Laval, Qc, Canada). Printing was performed at a center-to-center resolution of $200 \mu \mathrm{m}$ by accumulating a total of 110 droplets per spot ( $100 \mathrm{pl}$ per droplet). Profiling and IMS of tissue sections were performed on a MALDI Time-of-flight (TOF) mass spectrometer (Ultraflextreme, Bruker Daltonics, Billerica, MA, USA). MS data were acquired in the linear geometry 
with an accelerating potential of $25 \mathrm{kV}$ with delayed extraction parameters set for optimal resolving power between 4000 and 5000 amu. IMS data were automatically acquired with the FlexControl 3.4 software with a spatial resolution of $200 \mu \mathrm{m}$. Ion images were displayed and analyzed in FlexImaging 3.0. For comparison with histological data, serial $10 \mu \mathrm{m}$ sections were stained with haematein and eosin (H\&E) using standard protocols.

To confirm the results obtained with IMS, a $5 \mu \mathrm{L}$ of a $1: 1$ acetonitrile: $0.1 \%$ trifluoroacetic acid solution was left on the section $1 \mathrm{~min}$ and aspirated twice to dissolve the free peptide dried on the section. After centrifugation, the extract was analyzed by LC-MS/MS on a nanospray-LTQ-Orbitrap XL MS (Thermo Scientific, San Jose, CA, USA) using a C18 LC column (Chaurand, et al., 2007). The results were compared with the spectrum obtained from an ADDL stock solution.

\subsection{Statistical analysis}

Statistics were calculated using the GraphPad Prism statistical package (GraphPad Software, La Jolla, CA, USA). Student's t-test was used to compare control and injected groups. Statistical significance was set to a p value $<0.05$.

\section{Results}

\subsection{In vitro characterization of injectates}

ADDLs were considered toxic and usable for in vivo injection when they induced at least $50 \%$ of dendritic spine removal in mature hippocampal cultures (as described in (Lacor, et al., 2007)). Delipidated ADDLs had similar effects in vitro as regular ADDLs (data not shown). Unless noted, experiments were performed using regular ADDLs.

\subsection{Injected ADDLs detection in mouse brain}

ADDLs were detected 1 hour to 7 days post injection with various techniques.

MALDI MS analysis of brain tissue one hour after injection of ADDLs showed intense protein profiles in a mass range below 20,000. In particular, a signal at $\mathrm{m} / \mathrm{z} 4738.5$ corresponding to the protonated average mass of the biotinylated ADDL molecule was observed (Fig. 2). No signal at the same $\mathrm{m} / \mathrm{z}$ was observed from control brain 
sections. IMS analysis showed a large diffusion of ADDLs in both hemispheres one hour after their unilateral injection in the hippocampus. The identification of the signal observed at $\mathrm{m} / \mathrm{z} 4738.5$ as caused by ADDL was subsequently confirmed by LC-MS/MS performed following protein extraction from the studied histological samples.

ADDLs tagged with Fluor Hylite 555 could be directly detected after their injection. Five hours after injection, a diffuse fluorescent signal could be seen in the neuropil, strongest at the site of injection but still visible at a distance of $800 \mu \mathrm{m}$, from it on the rostro-caudal axis. At the site of injection, a fluorescent signal was detected in neurons (neurites and soma). It was attenuated 7 days post injection but could still be seen mostly at the injection site. It was found as granular material in the cell body and neurites of hippocampal neurons (Fig. 3 a)

Immunostaining with anti $\mathrm{A} ß(6 \mathrm{E} 10)$ and anti $\mathrm{A} ß$ oligomers (OC and NU1; see Fig. $3 \mathrm{a}-\mathrm{b})$ confirmed the widespread diffusion of the ADDLs five hours and seven days post injection. The signal detected by the different antibodies was both intracellular (in neuronal cell bodies), and extracellular (granular punctiform deposits in the neuropil). OC detection of $A ß$ seven days after injections was particularly sensitive, showing positive labeling in almost all brain regions at various rostro-caudal levels (Fig. 3b). While Aß-positive material was detected in brain tissue following ADDLs injection, no evidence of fibrillar deposits (i.e. thioflavin-S positive) was observed (Sup Fig $1 \mathrm{a}-\mathrm{b})$ underlining the non-aggregation of injected $\mathrm{A} ß$.

Biotinylated ADDLs were detected 7 days post injection throughout the whole brain in the injected mice (Fig. 3 c-d). The labeling of biotinylated ADDLs was mostly diffuse with an extra- and intra-cellular topography; neuron cell bodies were stained even in distant regions of the brain ( $2 \mathrm{~mm}$ anterior to the injection site (Fig. 3d). The same diffusion was observed with biotinylated ADDLs prepared in a delipidated medium (data not shown). No positive staining was observed in the 18 mice injected with control solution composed of vehicle plus free biotin

(Fig. 3c). Finally, no staining was observed when injected ADDLs were not biotinylated.

\subsection{Behavioral effects associated with ADDLs injection}

Six days post-surgery ADDLs injected mice explored the new arm of the maze at the chance level (33\%) during the retention trial and therefore did not display memory of the previously-explored arms (Fig. 4). Animals injected with control solution on the other hand explored the new arm 58\% of the time, hence showing a significant 
spatial bias underlining good recognition memory performance. The difference between the two groups was significant $(\mathrm{p}<0,0001)$. The same memory impairment was observed with retentate or delipidated ADDLs (ps <0.05). However mice injected with filtrate ADDLs did not differ from controls ( $p>0.34$ ). Behavioral measures of total distance travelled and average speed were not significantly different across the various groups analyzed (comparisons between control and ADDLs groups: all ps>0.21).

One month after injection two animals had to be removed from the analysis due to freezing behavior during the acquisition phase of the test. For the 16 remaining animals, both vehicle and ADDLs injected mice explored the new arm above chance level without any significant difference between the two groups $(\mathrm{p}>0.12)$

\subsection{Neuropathological consequences of ADDLs injections}

PSD95 immunoreactivity was decreased in ADDLs injected mice: seven days after injection of regular ADDLs, PSD95 ROD was significantly reduced in the hippocampus $(\mathrm{p}<0.025)$ but also at a distance from the injection site, i.e. in the prefrontal cortex ( $<<0.001$; Fig. 5). The injection of delipidated ADDLs had the same effect with PSD95 ROD decreased by $16 \%$ in the hippocampus $(\mathrm{p}<0.05)$ and by $14 \%$ in the prefrontal cortex $(\mathrm{p}<0.05)$. For the retentate ADDLs, a PSD95 ROD decrease was also observed in the hippocampus $(\mathrm{p}<0.05)$ and prefrontal regions ( $\mathrm{p}<0.01)$. Finally, in mice injected with filtrate ADDLs PSD95 ROD did not differ from controls.

Induced tau phosphorylation as detected by AT8 immunohistochemistry was observed 1 day and 7 days after injection of ADDLs in the hippocampus. The signal was diffuse, encompassing most of brain areas but mostly present in axon rich regions of the brain such as mossy fibers (Fig. 6). No individual tangle-like aggregates or pretangles could be visualized in neurons which was consistent with previous findings (Brouillette, et al., 2012). Visual assessment of the slides did not allow selecting a negative region that could have been used as a measure of the background noise; absence of such a reference area precluded the calculation of relative optical densities. Group comparisons were therefore assessed using OD (ADDLs vs. controls: all p's $<0.01$ in frontal cortex and dorsal hippocampi). No differences were observed between right (injected) and left (non-injected) hemispheres (p's $>0.07)$. The staining levels were also comparable in mice sacrificed 1 day and 7 days after injection $(\mathrm{p}=0.23)$.

Evoked neuronal activity assessed by fos immunostaining was globally increased in ADDLs injected mice as compared to controls ( $51 \%$ increase, $\mathrm{p}<0.01$; see Fig. 7). This increase of fos labeling was seen not only at the injection site in the hippocampus $(\mathrm{p}<0.05)$ but also at a distance from it, in the prefrontal cortex $(\mathrm{p}<0.001)$. 
To summarize, despite topical injection ADDLs induced widespread morpho-functional effects. In particular PSD95 ROD was reduced in both the ipsi- and contralateral hippocampi and frontal cortices. Similarly fos and tau changes were distributed equally in the two brain hemispheres of ADDLs-injected mice.

\section{Discussion}

We have shown histologically and by MS imaging that ADDLs injected in the hippocampus of wild type mice were detected diffusely in brain parenchyma within hours and could still be evidenced a week after. They were associated with tau hyperphosphorylation, decreased PSD95 and increased fos immunoreactivities and cognitive impairments. The cognitive changes were not evidenced one month after injection confirming the transient and reversible toxicity of oligomers as already exemplified by others (Balducci, et al., 2010, Youssef, et al., 2008). It is possible that more robust and stable phenotypes could be induced following chronic ADDLs administration mimicking gradual and continuous $\mathrm{A} ß$ accumulation. However, to our knowledge, the long-lasting effects of chronic oligomers administration remain to be explored.

There are probably many ways in which $\mathrm{A} ß$ oligomers (ADDLs in our study) are transported in the brain parenchyma. The term of spreading has been used to describe the slow progression of pathology within the brain of animals injected with misfolded proteins. A mechanism of "corruptive protein templating" has been postulated to explain $A \beta$ accumulation and the parallel development of alterations in connected territories (Jucker and Walker, 2011). Phases of brain amyloidosis in Man (Thal, et al., 2002) also suggest a slow progression of $A ß$ accumulation, initiating in the isocortex and gradually involving subcortical and deep brain regions.

In our experiments, the signal of $\mathrm{A} \beta$ was visualized by MS imaging at a large distance from the injection site within one hour. Histologically A $\beta$ oligomers were detected in injected brains by concurrent methods (fluorescent or biotin tags, immunohistochemistry with different anti-Aß antibodies). While no aggregated material was evidenced following ADDLs injection, $A ß$ was detected in neuronal perikarya close to the injection site and at a distance from it - indicating that $A \beta$ could cross the cell membranes. The large distribution of $A ß$ oligomers we depicted was however poorly compatible with a transport via neural connections as observed in vitro (Hong, et al., 2014) or in transgenic mice, with a time scale encompassing weeks or months (Eisele, 2013). The widespread distribution of the oligomers, observed in the extracellular space shortly after injection, rather suggests a diffusion process. Molecules, including high MW assemblies, passively diffuse in the extracellular space along concentration 
gradients with the usual motion constraints (diffusion coefficient, tortuosity) observed in confined media (Sykova and Vargova, 2008). The bulk flow in the perivascular space or along the basement membrane as well as the glymphatic flow of interstitial fluid could actively contribute to Aß diffusion (Abbott, 2004,Carare, et al., 2008,Xie, et al., 2013). Interestingly, no fibrillar Aß could be evidenced after ADDLs injection in the brains of wild type mice.

The rapid diffusion of oligomers was associated with an impairment of spatial short-term memory, a toxic effect consistent with previous reports relying on the use of natural or synthetic Aß oligomers (Balducci, et al., 2010,Brouillette, et al., 2012,Cleary, et al., 2005,Garcia, et al., 2010). The cognitive impairment of ADDLs-treated mice was associated with a loss of synaptic markers. We found a decrease of PSD95 immunoreactivity in ADDLsinjected mice, not only at the injection site but also at a distance from it, in the frontal cortex (as previously evidenced (Garcia, et al., 2010). The binding of $\mathrm{A} ß$ oligomers to synapses and neuronal membranes which has been assessed in vitro (Lacor, 2007,Lacor, et al., 2004,Renner, et al., 2010,Wilcox, et al., 2011) alters synaptic plasticity (Selkoe, 2008) and could be the source of the observed functional impairments.

Aß oligomers are also known to promote tau phosphorylation in vitro (De Felice, et al., 2008,Jin, et al., 2011,Zempel, et al., 2010) and in vivo (Brouillette, et al., 2012). In our experimental model we did observe a diffuse increase of AT8 immunostaining at the injection level and also in distant areas (frontal region). Other anti-tau antibodies did not discriminate vehicle- vs ADDLs-injected mice (data not shown. See (Brouillette, et al., 2012) for similar results). The widespread tau hyperphosphorylation detected by AT8 is not compatible with a toxicity involving a transport of $A \beta$ through connections; it is rather related to the direct effect of oligomers over a large area of diffusion.

Finally oligomers injections induced neuronal hyperactivity in the hippocampus (i.e. at the injection site) and at a distance in the frontal cortex. Overexpression of synaptic immediate early genes has been reported in neuronal cell cultures bathed with ADDLs (Lacor, et al., 2004). Oligomer-induced abnormal clustering of mGluR5 has been thought to cause neuronal hyperactivity (Renner, et al., 2010). Focal neuronal hyperactivity and increased neuronal metabolism have been previously reported in AD transgenic mice (Dubois, et al., 2010,Palop, et al., 2007). This neuronal hyperactivity could correspond to the brain activity changes reported in subjects at risk of AD or in patients at a preclinical stage of the disease (Bakker, et al., 2012,Dickerson and Sperling, 2008).

As the diffusion process of the ADDLs is widespread and very fast (the MALDI IMS analysis indicate that one hour after injection the ADDLs can already be found throughout all the studied brain section) no localized toxic 
effect (e.g. targeting the sole injected hippocampus) were observed. The rapid spreading of ADDLs explains the diffuse pattern of pathological markers (loss of PSD-95, increase in p-tau and fos immunoreactivities) observed in ADDLs-injected mice.

High molecular weight (HW) $\mathrm{A} ß$ assemblies (over $50 \mathrm{kDa}$, i.e. dodecamers and above) elicited the same memory and synaptic impairments as the total ADDLs preparation, contrary to the low molecular weight (LW) oligomers (<50 kDa). These data confirm some in vitro observations (Lacor, et al., 2007): HW ADDLs, but not LW ADDLs, bind to synapses and are synaptotoxic. This differential toxicity may be related to a lesser clearance of the HW vs. LW species from the brain (Takeda, et al., 2013). Interestingly HW Aß oligomers have been shown to be elevated in the cerebrospinal fluid of AD patients, suggesting their pathogenicity in the Human (Fukumoto, et al., 2010). Toxic effects of cellular supernatants containing $A \beta$ assemblies have concurrently been repeatedly attributed to dimers or trimers (Figueiredo, et al., 2013,Selkoe, 2008,Townsend, et al., 2006,Walsh, et al., 2002). The toxicity of these LW species still remains controversial (Lesne, 2013). Other A $\beta$ assemblies have been incriminated such as dodecamers $(\mathrm{A} \beta * 56)$ and the opinion has been expressed that it is currently impossible to attribute synaptotoxicity and associated morphological or functional changes to a single $A ß$ species (Benilova, et al., 2012). Our results show that, considering synthetic $\mathrm{A} B$ oligomers, only HW species promote toxic effects.

Unidentified partners that potentiate oligomers toxicity and diffusion cannot be excluded (Benilova, et al., 2012). We wondered if lipids contained in ADDLs preparations could serve as A $\beta$ partners and play, by themselves, a toxic role (Fantini, et al., 2014,Hong, et al., 2014,Martins, et al., 2008). We found that lipidated and delipidated ADDLs exerted the same toxicity. While it is noteworthy that oligomers of Aß do not need to be synthetized in a lipidic medium to induce toxicity, it is plausible that once injected they associate with brain lipids or other co-factors (Hong, et al., 2014).

In conclusion our injection experiments showed that oligomers are able to diffuse rapidly in the brain. They also exert a direct toxic effect as posited by the revised cascade hypothesis. By contrast, formation and dissemination of classical $A ß$ aggregates that start years before the onset of symptoms (Bateman, et al., 2012,Braak and Braak, 1997) are characteristic of the spreading of cerebral ß-amyloidosis (Jucker and Walker, 2011). Although the rapid diffusion and toxicity of oligomers of $\mathrm{A} \beta$ do not match the slow deposition of fibrillar $\mathrm{A} \beta$ plaques in $\mathrm{AD}$, soluble $\mathrm{A} \beta$ species could be the source of the subtle cognitive impairments going on for decades before AD dementia is 
diagnosed (Amieva, et al., 2014,Lesne, et al., 2013). Our injection model hence mimics acutely some critical early events of $\mathrm{AD}$ and demonstrates the high potential of $\mathrm{A} B$ oligomers to diffuse in tissue, thus giving a valuable opportunity for subsequent therapeutical or physiopathological studies targeted against these toxic species (Goure, et al., 2014).

\section{Acknowledgements}

The authors gratefully acknowledge support from the « Fondation pour la Recherche Médicale » (S.E.), the "Ligue Européenne contre la maladie d'Alzheimer"-LECMA (B.D.) and the "fondation Georges Pompidou" (B.D.). The present work was also supported by funding from the program "Investissements d'avenir ANR-10-IAIHU-06". The authors sincerely acknowledge the fruitful comments and advice from Dr. K. Ando during the redaction of the manuscript.

\section{Conflict of interest}

The authors declare that they have no conflict of interest.

\section{References}

Abbott, N.J. 2004. Evidence for bulk flow of brain interstitial fluid: significance for physiology and pathology. Neurochemistry international 45(4), 545-52.

Amieva, H., Mokri, H., Le Goff, M., Meillon, C., Jacqmin-Gadda, H., Foubert-Samier, A., Orgogozo, J.M., Stern, Y., Dartigues, J.F. 2014. Compensatory mechanisms in higher-educated subjects with Alzheimer's disease: a study of 20 years of cognitive decline. Brain 137(Pt 4), 1167-75. doi:10.1093/brain/awu035.

Bakker, A., Krauss, G.L., Albert, M.S., Speck, C.L., Jones, L.R., Stark, C.E., Yassa, M.A., Bassett, S.S., Shelton, A.L., Gallagher, M. 2012. Reduction of hippocampal hyperactivity improves cognition in amnestic mild cognitive impairment. Neuron 74(3), 467-74. doi:10.1016/j.neuron.2012.03.023.

Balducci, C., Beeg, M., Stravalaci, M., Bastone, A., Sclip, A., Biasini, E., Tapella, L., Colombo, L., Manzoni, C., Borsello, T., Chiesa, R., Gobbi, M., Salmona, M., Forloni, G. 2010. Synthetic amyloid-beta oligomers impair long-term memory independently of cellular prion protein. Proceedings of the National Academy of Sciences of the United States of America 107(5), 2295-300.

Bateman, R.J., Xiong, C., Benzinger, T.L., Fagan, A.M., Goate, A., Fox, N.C., Marcus, D.S., Cairns, N.J., Xie, X., Blazey, T.M., Holtzman, D.M., Santacruz, A., Buckles, V., Oliver, A., Moulder, K., Aisen, P.S., Ghetti, B., Klunk, W.E., McDade, E., Martins, R.N., Masters, C.L., Mayeux, R., Ringman, J.M., Rossor, M.N., Schofield, P.R., Sperling, R.A., Salloway, S., Morris, J.C., Dominantly Inherited Alzheimer, N. 2012. Clinical and biomarker changes in dominantly inherited Alzheimer's disease. N Engl J Med 367(9), 795-804. doi:10.1056/NEJMoa1202753. 
Benilova, I., Karran, E., De Strooper, B. 2012. The toxic Aß oligomer and Alzheimer's disease: an emperor in need of clothes. Nature neuroscience 15(3), 349-57.

Braak, H., Braak, E. 1997. Frequency of stages of Alzheimer-related lesions in different age categories. Neurobiol Aging 18(4), 351-7.

Braudeau, J., Dauphinot, L., Duchon, a., Loistron, a., Dodd, R.H., Hérault, Y., Delatour, B., Potier, M.C. 2011. Chronic Treatment with a Promnesiant GABA-A a5-Selective Inverse Agonist Increases Immediate Early Genes Expression during Memory Processing in Mice and Rectifies Their Expression Levels in a Down Syndrome Mouse Model. Advances in pharmacological sciences 2011, 153218-.

Brouillette, J., Caillierez, R., Zommer, N., Alves-Pires, C., Benilova, I., Blum, D., De Strooper, B., Buée, L. 2012. Neurotoxicity and Memory Deficits Induced by Soluble Low-Molecular-Weight Amyloid-ß142 Oligomers Are Revealed In Vivo by Using a Novel Animal Model. The Journal of neuroscience : the official journal of the Society for Neuroscience 32(23), 7852-61.

Carare, R.O., Bernardes-Silva, M., Newman, T.a., Page, a.M., Nicoll, J.a.R., Perry, V.H., Weller, R.O. 2008. Solutes, but not cells, drain from the brain parenchyma along basement membranes of capillaries and arteries: significance for cerebral amyloid angiopathy and neuroimmunology. Neuropathology and applied neurobiology 34(2), 131-44.

Chaurand, P. 2012. Imaging mass spectrometry of thin tissue sections: a decade of collective efforts. J Proteomics 75(16), 4883-92. doi:10.1016/j.jprot.2012.04.005.

Chaurand, P., Schriver, K.E., Caprioli, R.M. 2007. Instrument design and characterization for high resolution MALDI-MS imaging of tissue sections. Journal of mass spectrometry : JMS 42(4), 47689. doi:10.1002/jms.1180.

Chromy, B.A., Nowak, R.J., Lambert, M.P., Viola, K.L., Chang, L., Velasco, P.T., Jones, B.W., Fernandez, S.J., Lacor, P.N., Horowitz, P., Finch, C.E., Krafft, G.A., Klein, W.L. 2003. Self-assembly of Abeta(1-42) into globular neurotoxins. Biochemistry 42(44), 12749-60.

Cleary, J.P., Walsh, D.M., Hofmeister, J.J., Shankar, G.M., Kuskowski, M.A., Selkoe, D.J., Ashe, K.H. 2005. Natural oligomers of the amyloid-beta protein specifically disrupt cognitive function. Nature Neuroscience 8(1), 79-84.

Cornett, D.S., Reyzer, M.L., Chaurand, P., Caprioli, R.M. 2007. MALDI imaging mass spectrometry: molecular snapshots of biochemical systems. Nat Methods 4(10), 828-33. doi:10.1038/nmeth1094.

de Chaumont, F., Dallongeville, S., Chenouard, N., Herve, N., Pop, S., Provoost, T., Meas-Yedid, V., Pankajakshan, P., Lecomte, T., Le Montagner, Y., Lagache, T., Dufour, A., Olivo-Marin, J.C. 2012. Icy: an open bioimage informatics platform for extended reproducible research. Nat Methods 9(7), 690-6. doi:10.1038/nmeth.2075.

De Felice, F.G., Wu, D., Lambert, M.P., Fernandez, S.J., Velasco, P.T., Lacor, P.N., Bigio, E.H., Jerecic, J., Acton, P.J., Shughrue, P.J., Chen-Dodson, E., Kinney, G.G., Klein, W.L. 2008. Alzheimer's diseasetype neuronal tau hyperphosphorylation induced by $A$ beta oligomers. Neurobiology of aging 29(9), 1334-47.

Dickerson, B.C., Sperling, R.a. 2008. Functional abnormalities of the medial temporal lobe memory system in mild cognitive impairment and Alzheimer's disease: insights from functional MRI studies. Neuropsychologia 46(6), 1624-35.

Doody, R.S., Thomas, R.G., Farlow, M., Iwatsubo, T., Vellas, B., Joffe, S., Kieburtz, K., Raman, R., Sun, X., Aisen, P.S., Siemers, E., Liu-Seifert, H., Mohs, R., Alzheimer's Disease Cooperative Study Steering, C., Solanezumab Study, G. 2014. Phase 3 trials of solanezumab for mild-to-moderate Alzheimer's disease. N Engl J Med 370(4), 311-21. doi:10.1056/NEJMoa1312889.

Dubois, A., Herard, A.S., Delatour, B., Hantraye, P., Bonvento, G., Dhenain, M., Delzescaux, T. 2010. Detection by voxel-wise statistical analysis of significant changes in regional cerebral glucose 
uptake in an APP/PS1 transgenic mouse model of Alzheimer's disease. Neuroimage 51(2), 58698. doi:10.1016/j.neuroimage.2010.02.074.

Duyckaerts, C., Delatour, B.t., Potier, M.-C. 2009. Classification and basic pathology of Alzheimer disease. Acta neuropathologica 118(1), 5-36.

Eisele, Y.S. 2013. From soluble abeta to progressive abeta aggregation: could prion-like templated misfolding play a role? Brain Pathol 23(3), 333-41. doi:10.1111/bpa.12049.

Fantini, J., Di Scala, C., Yahi, N., Troadec, J.D., Sadelli, K., Chahinian, H., Garmy, N. 2014. Bexarotene blocks calcium-permeable ion channels formed by neurotoxic Alzheimer's ss-amyloid peptides. ACS Chem Neurosci. doi:10.1021/cn400183w.

Figueiredo, C.P., Clarke, J.R., Ledo, J.H., Ribeiro, F.C., Costa, C.V., Melo, H.M., Mota-Sales, A.P., Saraiva, L.M., Klein, W.L., Sebollela, A., De Felice, F.G., Ferreira, S.T. 2013. Memantine rescues transient cognitive impairment caused by high-molecular-weight abeta oligomers but not the persistent impairment induced by low-molecular-weight oligomers. J Neurosci 33(23), 9626-34. doi:10.1523/JNEUROSCI.0482-13.2013.

Fukumoto, H., Tokuda, T., Kasai, T., Ishigami, N., Hidaka, H., Kondo, M., Allsop, D., Nakagawa, M. 2010. High-molecular-weight beta-amyloid oligomers are elevated in cerebrospinal fluid of Alzheimer patients. FASEB J 24(8), 2716-26. doi:10.1096/fj.09-150359.

Games, D., Khan, K.M., Soriano, F.G., Keim, P.S., Davis, D.L., Bryant, K., Lieberburg, I. 1992. Lack of Alzheimer pathology after beta-amyloid protein injections in rat brain. Neurobiology of Aging 13(5), 569-76.

Garcia, P., Youssef, I., Utvik, J.K., Florent-Béchard, S., Barthélémy, V., Malaplate-Armand, C., Kriem, B., Stenger, C., Koziel, V., Olivier, J.-L., Escanye, M.-C., Hanse, M., Allouche, A., Desbène, C., Yen, F.T., Bjerkvig, R., Oster, T., Niclou, S.P., Pillot, T. 2010. Ciliary neurotrophic factor cell-based delivery prevents synaptic impairment and improves memory in mouse models of Alzheimer's disease. The Journal of neuroscience : the official journal of the Society for Neuroscience 30(22), 7516-27.

Gilman, S., Koller, M., Black, R.S., Jenkins, L., Griffith, S.G., Fox, N.C., Eisner, L., Kirby, L., Rovira, M.B., Forette, F., Orgogozo, J.M. 2005. Clinical effects of Abeta immunization (AN1792) in patients with AD in an interrupted trial. Neurology 64(9), 1553-62.

Goure, W.F., Krafft, G.A., Jerecic, J., Hefti, F. 2014. Targeting the proper amyloid-beta neuronal toxins: a path forward for Alzheimer's disease immunotherapeutics. Alzheimers Res Ther 6(4), 42. doi:10.1186/alzrt272.

Hardy, J., Selkoe, D.J. 2002. The amyloid hypothesis of Alzheimer's disease: progress and problems on the road to therapeutics. Science 297(5580), 353-6.

Hardy, J.A., Higgins, G.A. 1992. Alzheimer's disease: the amyloid cascade hypothesis. Science 256(5054), 184-5.

Holmes, C., Boche, D., Wilkinson, D., Yadegarfar, G., Hopkins, V., Bayer, A., Jones, R.W., Bullock, R., Love, S., Neal, J.W., Zotova, E., Nicoll, J.A.R. 2008. Long-term effects of Abeta42 immunisation in Alzheimer's disease: follow-up of a randomised, placebo-controlled phase I trial. Lancet 372(9634), 216-23.

Hong, S., Ostaszewski, B.L., Yang, T., O'Malley, T.T., Jin, M., Yanagisawa, K., Li, S., Bartels, T., Selkoe, D.J. 2014. Soluble Abeta Oligomers Are Rapidly Sequestered from Brain ISF In Vivo and Bind GM1 Ganglioside on Cellular Membranes. Neuron 82(2), 308-19. doi:10.1016/j.neuron.2014.02.027.

Jin, M., Shepardson, N., Yang, T., Chen, G., Walsh, D., Selkoe, D.J. 2011. Soluble amyloid beta-protein dimers isolated from Alzheimer cortex directly induce Tau hyperphosphorylation and neuritic degeneration. Proceedings of the National Academy of Sciences of the United States of America 108(14), 5819-24.

Jucker, M., Walker, L.C. 2011. Pathogenic protein seeding in alzheimer disease and other neurodegenerative disorders. Annals of neurology 70(4), 532-40. 
Kayed, R., Head, E., Sarsoza, F., Saing, T., Cotman, C.W., Necula, M., Margol, L., Wu, J., Breydo, L., Thompson, J.L., Rasool, S., Gurlo, T., Butler, P., Glabe, C.G. 2007. Fibril specific, conformation dependent antibodies recognize a generic epitope common to amyloid fibrils and fibrillar oligomers that is absent in prefibrillar oligomers. Molecular neurodegeneration 2, 18-.

Klein, W.L. 2002. Abeta toxicity in Alzheimer's disease: globular oligomers (ADDLs) as new vaccine and drug targets. Neurochemistry International 41(5), 345-52.

Lacor, P.N. 2007. Advances on the understanding of the origins of synaptic pathology in AD. Curr Genomics 8(8), 486-508. doi:10.2174/138920207783769530.

Lacor, P.N., Buniel, M.C., Chang, L., Fernandez, S.J., Gong, Y., Viola, K.L., Lambert, M.P., Velasco, P.T., Bigio, E.H., Finch, C.E., Krafft, G.A., Klein, W.L. 2004. Synaptic targeting by Alzheimer's-related amyloid beta oligomers. Journal of Neuroscience 24(45), 10191-200.

Lacor, P.N., Buniel, M.C., Furlow, P.W., Clemente, A.S., Velasco, P.T., Wood, M., Viola, K.L., Klein, W.L. 2007. Abeta oligomer-induced aberrations in synapse composition, shape, and density provide a molecular basis for loss of connectivity in Alzheimer's disease. Journal of Neuroscience 27(4), 796-807.

Lambert, M.P., Barlow, A.K., Chromy, B.A., Edwards, C., Freed, R., Liosatos, M., Morgan, T.E., Rozovsky, I., Trommer, B., Viola, K.L., Wals, P., Zhang, C., Finch, C.E., Krafft, G.A., Klein, W.L. 1998. Diffusible, nonfibrillar ligands derived from Abeta1-42 are potent central nervous system neurotoxins. Proc Natl Acad Sci U S A 95(11), 6448-53.

Lambert, M.P., Velasco, P.T., Chang, L., Viola, K.L., Fernandez, S., Lacor, P.N., Khuon, D., Gong, Y., Bigio, E.H., Shaw, P., De Felice, F.G., Krafft, G.A., Klein, W.L. 2007. Monoclonal antibodies that target pathological assemblies of Abeta. J Neurochem 100(1), 23-35. doi:10.1111/j.14714159.2006.04157.x.

Lesne, S.E. 2013. Breaking the Code of Amyloid- Oligomers. International journal of cell biology 2013, 950783. doi:10.1155/2013/950783.

Lesne, S.E., Sherman, M.A., Grant, M., Kuskowski, M., Schneider, J.A., Bennett, D.A., Ashe, K.H. 2013. Brain amyloid-beta oligomers in ageing and Alzheimer's disease. Brain 136(Pt 5), 1383-98. doi:10.1093/brain/awt062.

Martins, I.C., Kuperstein, I., Wilkinson, H., Maes, E., Vanbrabant, M., Jonckheere, W., Van Gelder, P., Hartmann, D., D'Hooge, R., De Strooper, B., Schymkowitz, J., Rousseau, F. 2008. Lipids revert inert Abeta amyloid fibrils to neurotoxic protofibrils that affect learning in mice. EMBO Journal 27(1), 224-33.

McLean, C.A., Cherny, R.A., Fraser, F.W., Fuller, S.J., Smith, M.J., Beyreuther, K., Bush, A.I., Masters, C.L. 1999. Soluble pool of Abeta amyloid as a determinant of severity of neurodegeneration in Alzheimer's disease. Ann Neurol 46(6), 860-6.

Moon, M., Choi, J.G., Nam, D.W., Hong, H.S., Choi, Y.J., Oh, M.S., Mook-Jung, I. 2011. Ghrelin ameliorates cognitive dysfunction and neurodegeneration in intrahippocampal amyloid-beta1-42 oligomerinjected mice. J Alzheimers Dis 23(1), 147-59. doi:10.3233/JAD-2010-101263.

Moser, M.B., Moser, E.I., Forrest, E., Andersen, P., Morris, R.G. 1995. Spatial learning with a minislab in the dorsal hippocampus. Proc Natl Acad Sci U S A 92(21), 9697-701.

Olivo-Marin, J.C. 2002. Extraction of spots in biological images using multiscale products. Pattern Recognition 35(9), 1986-96.

Palop, J.J., Chin, J., Roberson, E.D., Wang, J., Thwin, M.T., Bien-Ly, N., Yoo, J., Ho, K.O., Yu, G.Q., Kreitzer, A., Finkbeiner, S., Noebels, J.L., Mucke, L. 2007. Aberrant excitatory neuronal activity and compensatory remodeling of inhibitory hippocampal circuits in mouse models of Alzheimer's disease. Neuron 55(5), 697-711.

Paxinos, G., Franklin, K.B.J. 2004. The Mouse Brain in Stereotaxic Coordinates: Compact Second Edition., San Diego, CA. 
Pearson-Leary, J., McNay, E.C. 2012. Intrahippocampal administration of amyloid-beta(1-42) oligomers acutely impairs spatial working memory, insulin signaling, and hippocampal metabolism. J Alzheimers Dis 30(2), 413-22. doi:10.3233/JAD-2012-112192.

Renner, M., Lacor, P.N., Velasco, P.T., Xu, J., Contractor, A., Klein, W.L., Triller, A. 2010. Deleterious Effects of Amyloid ß Oligomers Acting as an Extracellular Scaffold for mGluR5. Neuron 66(5), 73954.

Salloway, S., Sperling, R., Fox, N.C., Blennow, K., Klunk, W., Raskind, M., Sabbagh, M., Honig, L.S., Porsteinsson, A.P., Ferris, S., Reichert, M., Ketter, N., Nejadnik, B., Guenzler, V., Miloslavsky, M., Wang, D., Lu, Y., Lull, J., Tudor, I.C., Liu, E., Grundman, M., Yuen, E., Black, R., Brashear, H.R., Bapineuzumab, Clinical Trial, I. 2014. Two phase 3 trials of bapineuzumab in mild-to-moderate Alzheimer's disease. N Engl J Med 370(4), 322-33. doi:10.1056/NEJMoa1304839.

Schindelin, J., Arganda-Carreras, I., Frise, E., Kaynig, V., Longair, M., Pietzsch, T., Preibisch, S., Rueden, C., Saalfeld, S., Schmid, B., Tinevez, J.Y., White, D.J., Hartenstein, V., Eliceiri, K., Tomancak, P., Cardona, A. 2012. Fiji: an open-source platform for biological-image analysis. Nat Methods 9(7), 676-82. doi:10.1038/nmeth.2019.

Selkoe, D.J. 2008. Soluble oligomers of the amyloid beta-protein impair synaptic plasticity and behavior. Behavioural brain research 192(1), 106-13.

Stine Jr, W.B., Dahlgren, K.N., Krafft, G.A., LaDu, M.J. 2003. In vitro characterization of conditions for amyloid-beta peptide oligomerization and fibrillogenesis. Journal of Biological Chemistry 278(13), 11612-22.

Sykova, E., Vargova, L. 2008. Extrasynaptic transmission and the diffusion parameters of the extracellular space. Neurochem Int 52(1-2), 5-13. doi:10.1016/j.neuint.2007.04.007.

Takeda, S., Hashimoto, T., Roe, A.D., Hori, Y., Spires-Jones, T.L., Hyman, B.T. 2013. Brain interstitial oligomeric amyloid beta increases with age and is resistant to clearance from brain in a mouse model of Alzheimer's disease. FASEB J 27(8), 3239-48. doi:10.1096/fj.13-229666.

Terleph, T.A., Tremere, L.A. 2006. The Use of Immediate Early Genes as Mapping Tools for Neuronal Activation: Concepts and Methods. Springer Science, pp 1-10.

Thal, D.R., Rub, U., Orantes, M., Braak, H. 2002. Phases of A beta-deposition in the human brain and its relevance for the development of AD. Neurology 58(12), 1791-800.

Townsend, M., Shankar, G.M., Mehta, T., Walsh, D.M., Selkoe, D.J. 2006. Effects of secreted oligomers of amyloid beta-protein on hippocampal synaptic plasticity: a potent role for trimers. 572(Pt 2), 477-92.

Walsh, D.M., Klyubin, I., Fadeeva, J.V., Cullen, W.K., Anwyl, R., Wolfe, M.S., Rowan, M.J., Selkoe, D.J. 2002. Naturally secreted oligomers of amyloid beta protein potently inhibit hippocampal longterm potentiation in vivo. Nature 416(6880), 535-9.

Wilcox, K.C., Lacor, P.N., Pitt, J., Klein, W.L. 2011. Aß Oligomer-Induced Synapse Degeneration in Alzheimer's Disease. Cellular and molecular neurobiology.

Xie, L., Kang, H., Xu, Q., Chen, M.J., Liao, Y., Thiyagarajan, M., O'Donnell, J., Christensen, D.J., Nicholson, C., Iliff, J.J., Takano, T., Deane, R., Nedergaard, M. 2013. Sleep drives metabolite clearance from the adult brain. Science 342(6156), 373-7. doi:10.1126/science.1241224.

Youssef, I., Florent-Béchard, S., Malaplate-Armand, C., Koziel, V., Bihain, B., Olivier, J.-L., LeiningerMuller, B., Kriem, B., Oster, T., Pillot, T. 2008. N-truncated amyloid-beta oligomers induce learning impairment and neuronal apoptosis. Neurobiology of aging 29(9), 1319-33.

Zempel, H., Thies, E., Mandelkow, E., Mandelkow, E.-M. 2010. Abeta oligomers cause localized Ca(2+) elevation, missorting of endogenous Tau into dendrites, Tau phosphorylation, and destruction of microtubules and spines. The Journal of neuroscience : the official journal of the Society for Neuroscience 30(36), 11938-50. 


\section{Figure legends}

Fig. 1 Flowchart of mice population. The arrow represents time. Each time point is represented by a dashed perpendicular line (namely at 1 and 5 hours (H1, H5), 6, 7 and 30 days (D6, D7, D30) after injection). ADDLs: A $\beta$ derived diffusible ligands, dADDLs: delipidated ADDLs, rADDLs: retentate ADDLs (>50KDa), fADDLs: filtrate ADDLs (<50KDa), scrADDLs: scrambled ADDLs, VEH: Vehicle solution, FH555-ADDLs: fluor hylite 555 tagged ADDLs, IHC: immunohistochemistry. MS imaging: Mass spectrometry imaging

Fig. 2 Short-term ADDLs diffusion (1 hour post injection). Partial MALDI MS protein profile acquired from a brain section showing a signal at m/z 4738.5 corresponding to the biotinylated ADDL one hour after injection (a). This signal was not observed in control animals injected with vehicle+biotin. Coronal brain sections distribution of $\mathrm{m} / \mathrm{z}$ 4738.5 monitored by imaging MS showed positive signal in ADDL-injected mice (ADDL, (b)) but not in vehicleinjected animals (VEH, (c))

Fig. 3 Long-term ADDLs diffusion (7 days post-injection): The ADDLs can be observed in the soma (arrowhead) and dendrites (arrow) of hippocampal neurons. On the left, Hylite 555 tagged ADDLs are directly visualized in the CA1 of the injected hippocampus. On the right, in another mouse, regular ADDLs are stained by the NU1 antibody in the same hippocampal area. Both the soma (arrowhead) and neurites (arrows) of the neurons are stained (a). OC immunohistochemistry also allowed the specific detection of $A ß$, one week after its injection, in the cytoplasm of neurons (arrowheads), both in the hippocampus and in frontal cortex (b). Biotinylated ADDLs (ADDLs) but not biotin alone $(\mathrm{VEH})$ can be revealed 7 days after injection using avidin-biotin amplification (c-d; * represents the locus of the injection site for each mice). Three representative animals of each group (1-3: Vehicle+biotin injected, 4-6: Biotinylated ADDLs injected) are presented with an illustration of the biotin labelling along the brain rostrocaudal axis (distance between sections: $800 \mu \mathrm{m}$ ). A widespread diffusion of ADDLs was identified even at a distance from the right hippocampus and in the cytoplasm of cortical neurons (magnified inset in d). No neuronal staining was observed in control animals.

Fig. 4 Memory assessment. 
The ADDLs injected mice (ADDLs) have short term spatial memory impairment as evidenced by the reduced amount of time they spend exploring the new arm in a Y-Maze paradigm in contrast to vehicle injected mice (VEH). ADDLs injected mice indeed explored the new arm of the maze at the chance level (33\%).

Fig. 5 PSD95 Relative optical densities (ROD)

Optical densities (OD) of PSD95 immunostaining were measured in the prefrontal cortex (a) and dorsal hippocampus (b). Relative optical densities were obtained with the OD of the corpus callosum as internal reference. ROD values were normalized by the mean value of control mice across different experimental conditions. ADDLs as well as dADDLs and rADDLs (but not fADDLs) induced a decrease in PSD95 immunostaining ROD compared to control injections (c). * p $<0.05, * * \mathrm{p}<0.01, * * * \mathrm{p}<0.001$

Fig. 6 AT8 immunostaining optical densities (OD). 7 days after an injection of ADDLs or vehicle (VEH) AT8 immunostaining ODs were assessed in the frontal cortex (a) and dorsal hippocampus (b). Significant increase of tau phosphorylation was observed in both regions. ** $\mathrm{p}<0.01, * * * \mathrm{p}<0.001$

Fig. 7 Fos immunostaining. ADDLs injected mice and controls were sacrificed $90 \mathrm{mn}$ after a behavioral stimulation at $\mathrm{D}+7$ post-injection. Fos immunostaining was then performed to assess the evoked neuronal activity. The ratio of fos immunolabeled surface to the surface of the region of interest (prefrontal cortex (a) or hippocampus (b)) was significantly increased in ADDLs injected mice in both regions. ${ }^{*} \mathrm{p}<0.05 * * \mathrm{p}<0.01$ 
Table 1: Antibodies used in this study

\begin{tabular}{|c|c|c|c|c|}
\hline Primary Antibodies & Clonality & Dilution & Target & Origin \\
\hline $6 \mathrm{E} 10$ & M & $\begin{array}{l}1: 1000 \\
\mathrm{IF} / \mathrm{IP}\end{array}$ & $\begin{array}{c}A ß \text { amino acids } \\
3-8\end{array}$ & $\begin{array}{c}\text { Covance } \\
\text { Paris, France }\end{array}$ \\
\hline OC & $P$ & $\begin{array}{l}1: 1000 \\
\text { IF }\end{array}$ & $\begin{array}{l}\text { Amyloid fibrils and } \\
\text { prefibrillar oligomers }\end{array}$ & $\begin{array}{l}\text { StressMarq (Euromedex) } \\
\text { Mundolsheim, France }\end{array}$ \\
\hline PSD95 & $P$ & $\begin{array}{l}\text { 1:1000 } \\
\text { IP }\end{array}$ & $\begin{array}{l}\text { PSD95 amino acids 50- } \\
150\end{array}$ & $\begin{array}{c}\text { ABCAM } \\
\text { Paris, France }\end{array}$ \\
\hline Fos & $P$ & $\begin{array}{l}1: 1000 \\
\text { IP }\end{array}$ & $\begin{array}{l}\text { amino acids } \\
4-17 \text { of fos }\end{array}$ & $\begin{array}{l}\text { Calbiochem Merck KGaA, } \\
\text { Darmstadt, Germany }\end{array}$ \\
\hline AT8- biot & M & $\begin{array}{l}10000 \\
\text { IP }\end{array}$ & pSer202/pThr205 of tau & $\begin{array}{c}\text { Thermo Fisher Rockford, } \\
\text { IL, USA }\end{array}$ \\
\hline Secondary Antibodies & Dilution & Conjugate & & Origin \\
\hline Goat Anti-mouse IgG $(\mathrm{H}+\mathrm{L})$ & $1: 400$ & Biotinylated & & $\begin{array}{l}\text { Vector labs } \\
\text { Les Ulis,France }\end{array}$ \\
\hline Goat anti-rabbit IgG $(\mathrm{H}+\mathrm{L})$ & $1: 400$ & Biotinylated & & Vector labs \\
\hline
\end{tabular}


Goat Anti-mouse $(\mathrm{H}+\mathrm{L})$

$1: 200$

Alexa Fluor 488

Goat anti-Rabbit $(\mathrm{H}+\mathrm{L})$

$1: 200$

Dylight-Cy3

M: monoclonal, P: Polyclonal, IP: immunoperoxydase, IF: Immunofluorescence
Invitrogen

Cergy Pontoise,

France

$\mathrm{kPL}$

Gaithersburg, MD, USA 


\begin{tabular}{|c|c|c|c|c|c|}
\hline & \begin{tabular}{l||l} 
H1 & H5
\end{tabular} & D6 & D7 & & D30 \\
\hline Surgery & $\begin{array}{c}\text { MS } \\
\text { Imaging of } \\
A B \\
\text { ADDLs } n=4 \\
\text { VEH } n=4 \\
\\
\text { Direct } \\
\text { visualization of } \\
\text { FH555-ADDLs } \\
n=5 \\
\text { VEH } n=2\end{array}$ & $\begin{array}{c}\vdots \\
\text { Cognitive } \\
\text { evaluation } \\
\text { ADDLs } n=21 \\
\text { dADDLs } n=6 \\
\text { VEH } n=12 \\
\text { SCrADDLs } n=8\end{array}$ & & 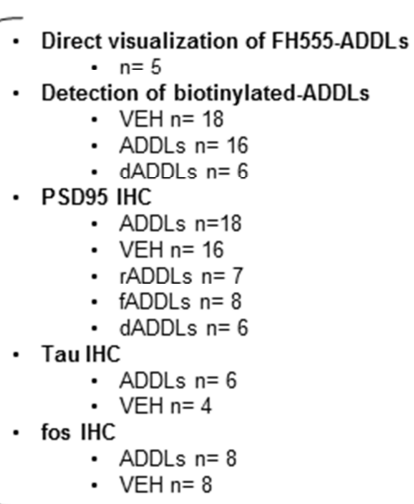 & $\begin{array}{c}\vdots \\
\text { Cognitive } \\
\text { evaluation } \\
\text { ADDLs } n=10 \\
\text { VEH } n=8\end{array}$ \\
\hline
\end{tabular}



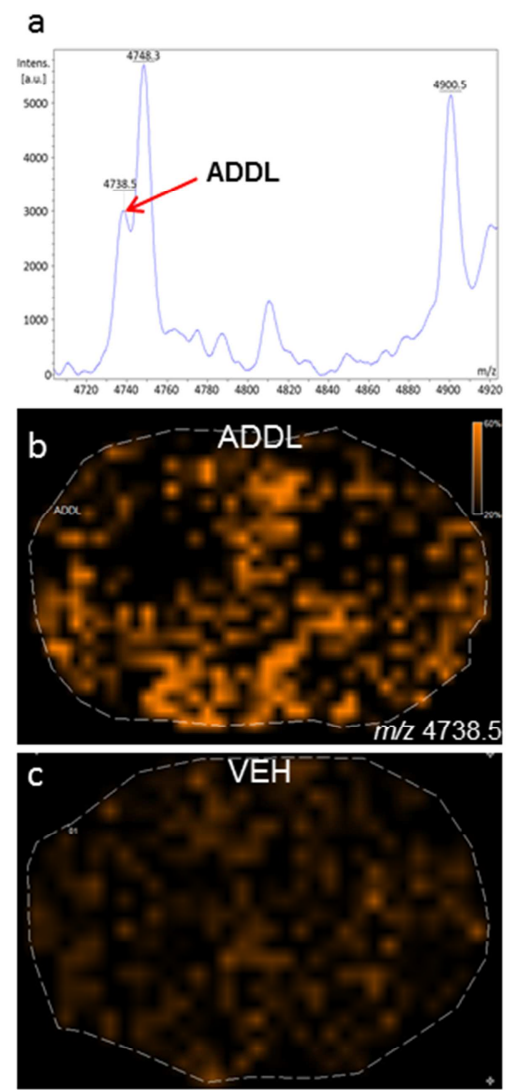

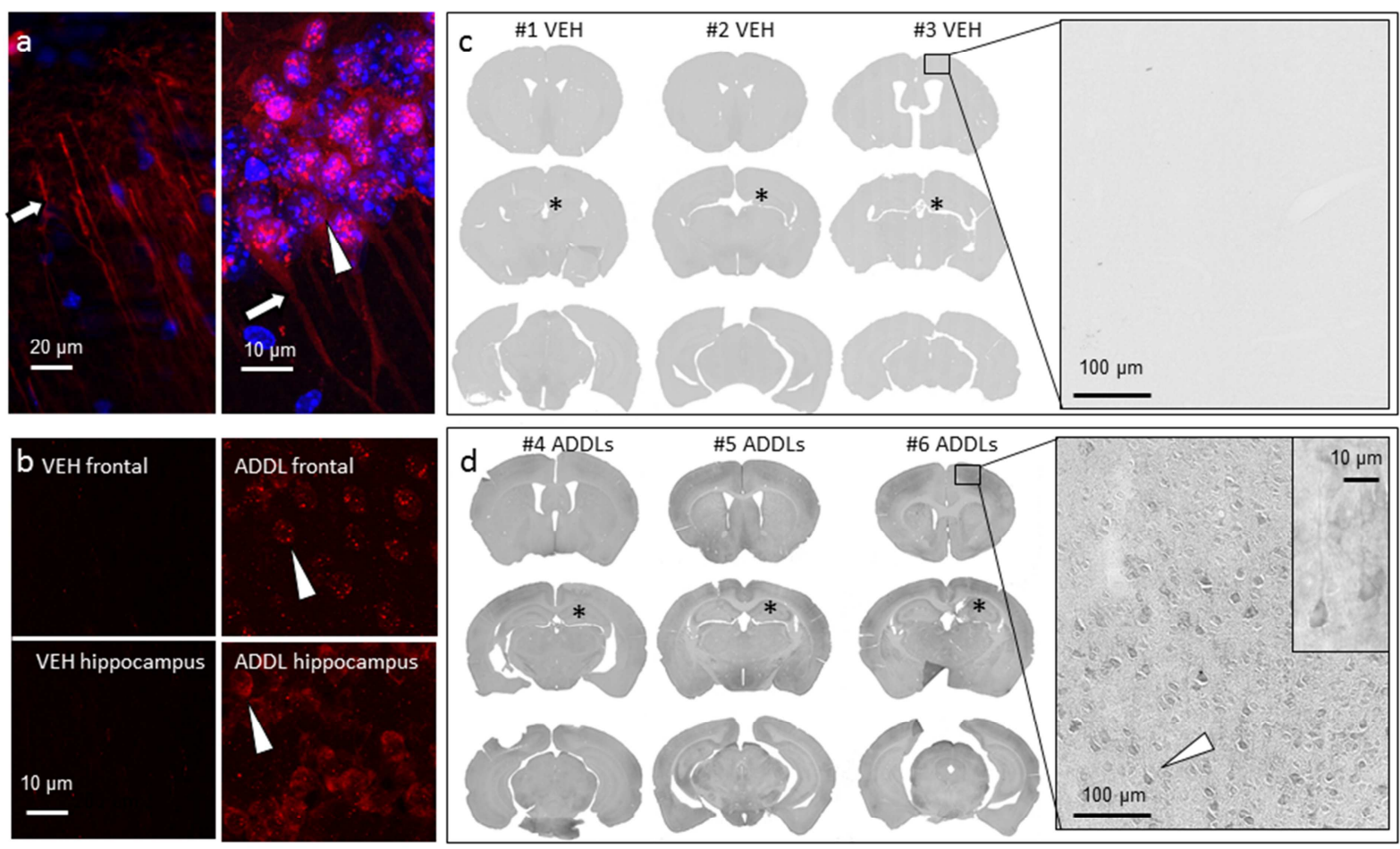


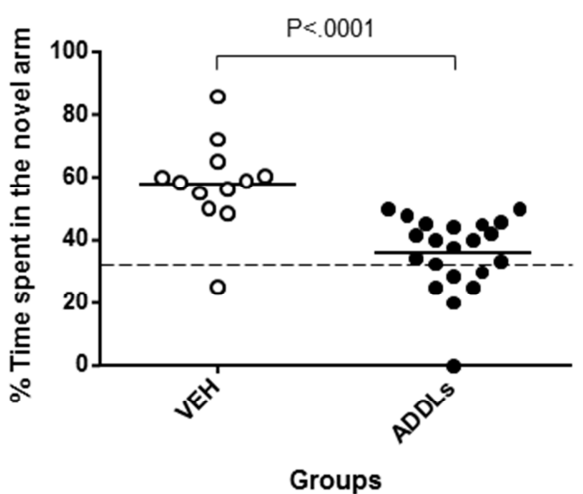


a

VEH

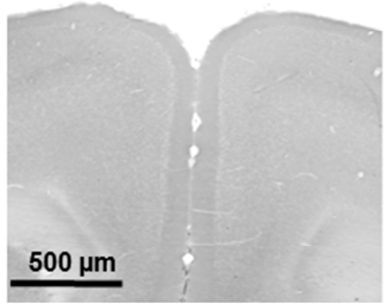

b

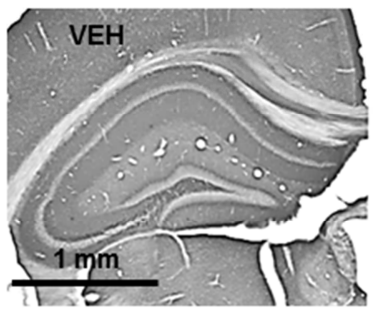

C

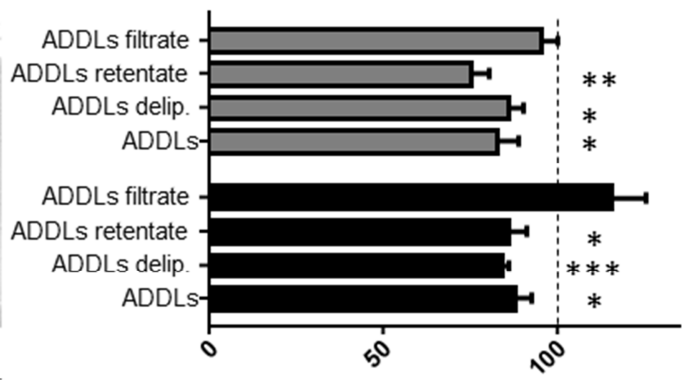

PSD95 staining (ROD \% of control)

$\square$ Prefrontal cortex

- Hippocampus 
a
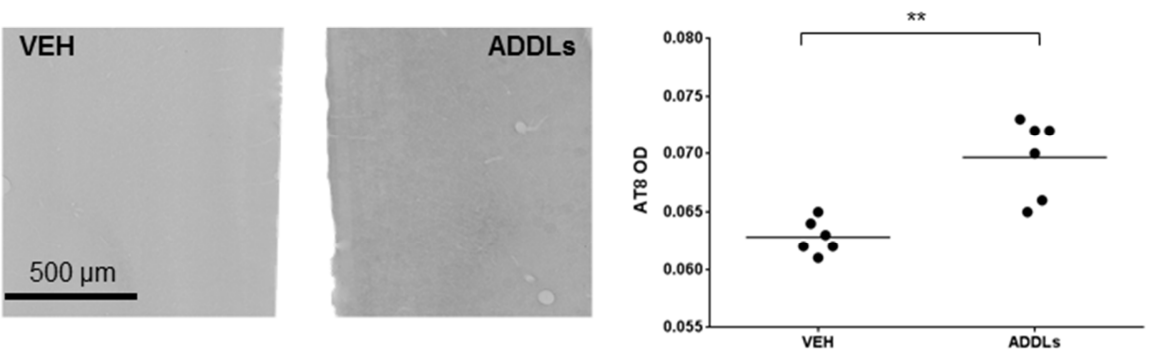

b
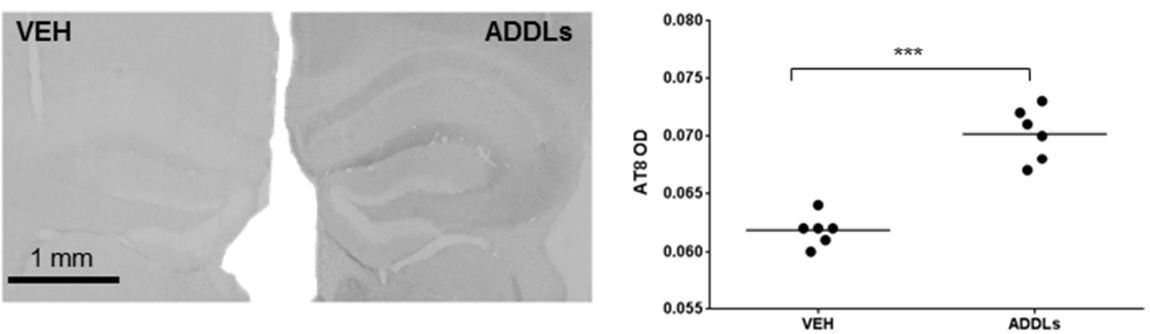
a
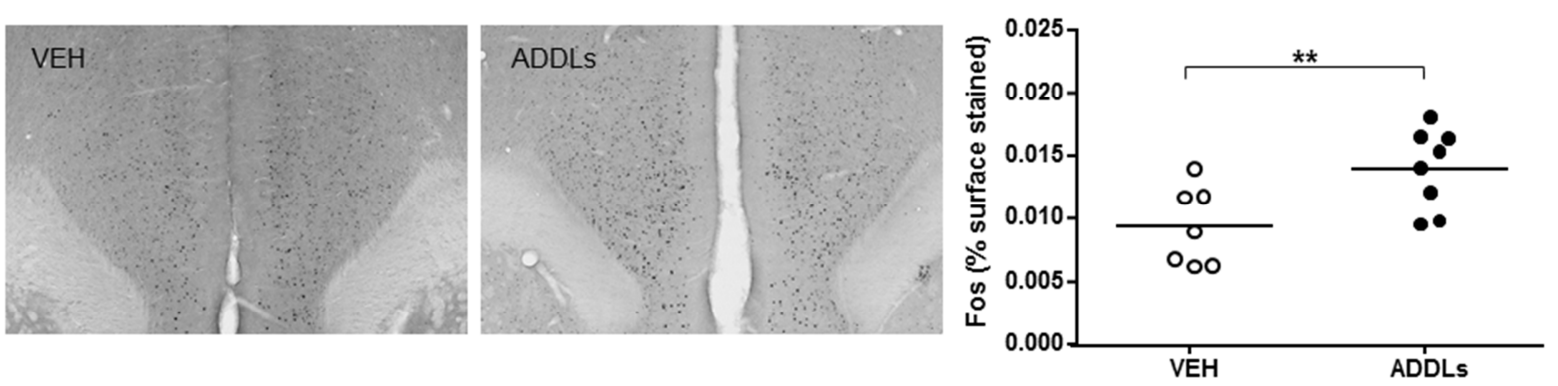

b
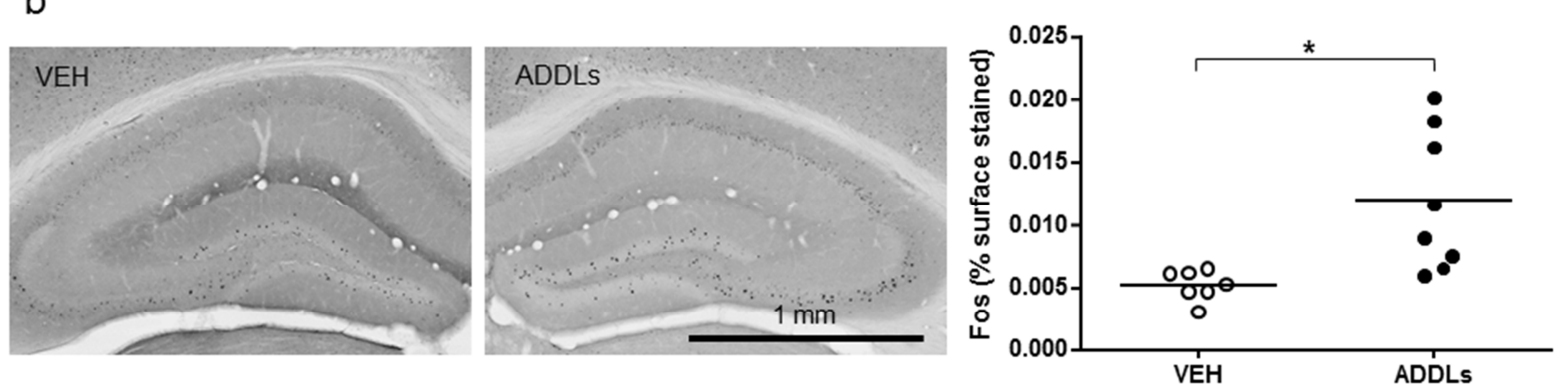
Highlights

- We injected $A ß$ oligomers in wild type mice brains.

- It induced memory and histological changes reminiscent of Alzheimer's disease

- This might be due to their large diffusion pattern observed in 4 concurrent methods 


\title{
Acute amnestic encephalopathy in amyloid- $\beta$ oligomers injected mice is due to their widespread diffusion in vivo
}

\author{
Supplementary Data \\ Table of contents \\ 1) Supplementary Material and Methods \\ 2) Supplementary results \\ 3) Supplementary Fig. 1 \\ 4) Supplementary Reference
}

\section{1) Supplementary Material and Methods}

To assess the presence of fibrillar A $B$ in ADDLs injected mice we performed a Thioflavin-S (SigmaAlrich) staining in injected mice one week after surgery and also in one transgenic mouse overexpressing mutant APP and developing florid brain amyloidosis (APPxPS1 Ki line described in (Casas, et al., 2004)) as a positive control. All mounted sections were reacted with aqueous thioflavin-S $1 \%$ for $2 \mathrm{~min}$, followed by differentiation in $70 \%$ ethanol and final rinsing' in water.

In addition, two young APPxPS1-Ki mice (less than 3 months old) were used to investigate early oligomers deposition in brain tissue (immunohistochemistry using the anti-ADDL NU1 antibody) from animals developing progressive brain amyloidosis. Double immunofluorescent staining were performed using the NU1 antibody and a pan-Aß standard antibody (4G8, 1:10 000, Covance, Paris, France). 


\section{2) Supplementary Results}

While APPxPS1 Ki mice exhibited prominent fibrillar Aß pathology after Thioflavin S staining (Sup Fig 1a), no such staining could be evidenced in ADDLs injected mice, even at the hippocampal locus of injection (Sup Fig. 1b).

Double immunostaining using standard anti-Aß (4G8) and anti-Aß oligomers antibodies indicate that, in young APPxPS1-Ki transgenic mice, the deposition of $\mathrm{A} B$ oligomers predates the formation of mature amyloid plaques (Sup Fig. 1 c-d). 


\section{ACCEPTED MANUSCRIPT}

\section{3) Supplementary Fig. 1}

Thioflavin S staining of one 3-months old APPxPS1-Ki mouse showing fibrillar Aß plaques (a) and of an ADDLs injected mouse with no visible signal even in the ADDLs injected hippocampus (b). Double immunofluorescent labeling of $A ß$ plaques (revealed by the $4 G 8$ antibody - red labeling) and of $A B$ oligomers deposits (NU1 - green labeling). NU1 immunoreactivity was detected as a peripheral, lightly organized, corona around the 4G8 positive cores of plaques. More importantly small-sized deposits, only immunodetected by the NU1 antibody (arrowheads) were also observed.(c-d)
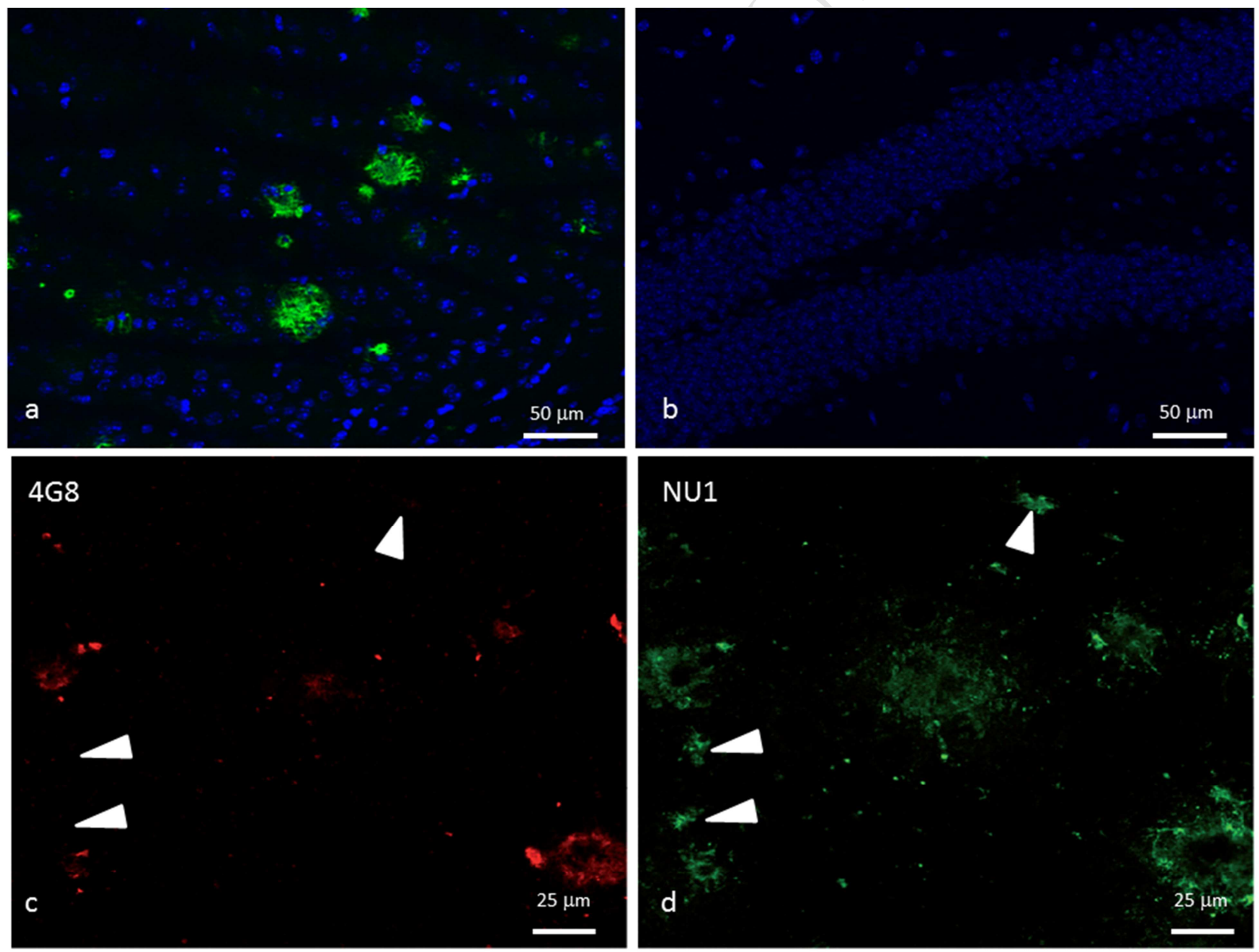


\section{4) Supplementary Reference}

Casas, C., Sergeant, N., Itier, J.M., Blanchard, V., Wirths, O., van der Kolk, N., Vingtdeux, V., van de Steeg, E., Ret, G., Canton, T., Drobecq, H., Clark, A., Bonici, B., Delacourte, A., Benavides, J., Schmitz, C., Tremp, G., Bayer, T.A., Benoit, P., Pradier, L. 2004. Massive CA1/2 neuronal loss with intraneuronal and N-terminal truncated Abeta42 accumulation in a novel Alzheimer transgenic model. American Journal of Pathology 165(4), 1289-300. 